\title{
Risks of political non-decision-making (applications to Ukraine)
}

UDC 321.02

DOI https://doi.org/10.24195/2414-

9616.2020-5.5

Vinnykova Nataliya Anatoliivna

Candidate of Political Science,

Associate Professor,

Associate Professor at the Department of Political Science

V. N. Karazin Kharkiv National University

Svobody sq., 4, Kharkiv, Ukraine

\begin{abstract}
This work presents an attempt to expand the research perspective as for the turbulent developments in international relations over the past few years, in particular regarding conflict situation in Ukraine. As a methodological benchmark it has been taken assumptions of the concepts of non-decision and risks selective regulation.

The purpose of the article is to to reveal the most significant non-decisions in Ukraine's domestic and foreign affairs, since getting independence, led to essential delay of reforms, the lack of a clear position on the international arena, and internal disintegration of society, contributed to the enhancing of frustration tendencies and resulted in inner social crisis, conflict with Russia and loss of sovereignty over a part of territory: Donetsk and Lugansk regions and Crimea peninsula. As the internal crisis in Ukraine caused tension between European countries and Russia, the EU foreign policy regarding its Eastern neighbors and, particularly, Ukraine is also included into the analysis.

Present work evaluates the non-decision as a selective technique of regulating political processes. Such an approach enables to include both reasons and consequences of nondecision into estimating the process of decision-making. In the theoretical aspect, we tried to challenge the key statement that a selective approach to decision-making is designed to ensure the stability of the political system. It is argued that the failure to approve decisions by using manipulative and heresthetic techniques in policy-making can have a destructive influence, and eventually lead to erosion of the political system.

The analysis of theoretical developments, institutional arrangements and political practices of preventing decision-making led to a conclusion as follows: i) the comprehensive study of the effects of any political decision must include an analysis of potential scenarios of its non-decision; ii) the functional part of the political system, namely the regulation of social risks, ensures the creation of collective rules and allows entities to act on the stable social expectations, in trying to exclude risk and frustration, which may cause shock-events, from the social life. Thereby, this study aimed to show how selective approach to decision-making, bringing short-term dividends, in long term and systematic use carries serious risks for all involved parties.

Key words: decision-making, non-decisions, mobilization of bias, Ukraine.
\end{abstract}

Introduction. The research of political crises is mainly focused on their causes and development scenarios. As a general tendency, some objective factors affecting the crisis are emphasized, i.e. economics, demographics, religious and cultural, or historical precedents. Yet, the political sphere presupposes dominating subjective factors, mostly related to the decisions on solving complex social issues. Political decisions are passed in a political framework, which has specific functions of "regulating selectively the distribution of social risks, and so of reducing fear, through the competitive allocation of security values" [28, p. 38].

The principle of including/excluding certain issues in political processes determines a selective nature of political decision-making. Selectivity of the political decision-making has been formalized first in the non-decision-theory started by Bachrach and Baratz [3-5] and developed through the critical re-estimation by Frey [10], McGrew and Wilson [18]. Further, it has been introduced in agenda-setting studies (Riker [19]) and the conception of selective regulating social risks (Zolo [28]). Applied research in this area is mainly focused on non-decisions in local policy-making (Gregory [12], Sammon and McAvinue [22]) and in international politics (Judge [15]).

Studying political decisions mainly concentrates on either the personal or the normative aspects.
However, the integral element of decision-making conscious or unconscious exclusion of certain issues out of the public sphere - is often ignored. In order to reach a political stability, the authorities need to establish certain structures of decision-making, but also have to use a wider range of filters for previous selections, which Bachrach and Baratz called «non-decisions» [4], that is considered as «the second face of power» [3]. The first (visible) face embodied the power and reflects it in concrete decisions or activities aimed directly at those decisions, and the second (hidden) face power is the possibility, when «some person or association could limit decision-making to relatively non-controversial matters, by influencing community values and political procedures and rituals, notwithstanding that there are in the community serious but latent power conflicts» [3, p. 949]. Thus, non-decision-making is "a means, by which demands for change in the existing allocation of benefits and privileges in the community can be suffocated before they are even voiced" [5, p. 44].

If one uses the definition of functions of power suggested by Lukes [17, p. 28], it becomes apparent the practice of non-decision is implemented when the most influential members of the group or community decisively and effectively manipulate the situation in order to prevent individual frustration turn into 
full-blown problems that Schattschneider defined as "mobilization of bias: some issues are organized into politics while others are organized out" [23, p. 71].

Special theoretical debates highlighted the question - what exactly non-decisions are and how they correlate with non-issues. In this debate Frey offered to separate "the formal yet uncinated decision of government, as manifested in bills, laws, regulations, hearing and the like" from the issues presenting «"those topics that appear in community newspapers and other media over a stipulated period" [10, p. 1083]. Yet, we support the opinion of McGrew and Wilson, claiming that, "in many cases non-decisions are decisions" [18, p. 25]. This is decision, which obviously is not formalized by authorities and not submitted to the agenda.

To analyze this approach to non-decisions Riker introduced the concept of heresthetic, calling the strategy, which aims to obtain an advantage through manipulation of circumstances in which a political choice is made. Heresthetic methods can be split into two categories, depending on whether they operate through the agenda or assessment criteria. Governmental officials, such as speakers of the legislative body or meeting chairpersons can influence the political outcome in some way by forming a decision-making process. Sometimes they can do it directly in their interests, abandoning consideration of various alternatives - perhaps justifying the actions with the demand to become more familiar with the issue. Another time they can achieve their goals by determining the order of consideration of alternatives. Whoever forms the agenda is in a winning position, because the issue included into it will be registered as political course. Another way is to mobilize other political actors in one's benefit so as locking suggestions would cost much to the creators of agenda.

It is hard to identify latent manipulative practices that lead to the exclusion or restriction of certain categories of interests from the political agenda. Politicians can manipulate by information that is put into the decision-making and deliberately avoiding or distorting statements of those whose opinions may differ. Prevention of decision-making in this way can take place when alternative ideas and approaches are leveled off in the sake of national interest.

The armed conflict in Ukraine and the tense relations between Western countries and Russia lately have become of the top research topics. Current conflict in Ukraine is generally considered as a proxy conflict between the West and Russia, which occurred as a result of a dissonance between Russia's viewing its role in the global arena and attempts of European elites to extrapolate neoliberal principles on relations with Russia. We argue, that Ukrainian crisis should be considered more thoroughly, including the analysis of non-decisions on strategically important issues during the entire period of Ukrainian independence.
The purpose and tasks. The purpose of the article is to to reveal the most significant non-decisions in Ukraine's domestic and foreign affairs, since getting independence, contributed to the enhancing of frustration tendencies and resulted in inner social crisis, conflict with Russia and loss of sovereignty over a part of territory: Donetsk and Lugansk regions and Crimea peninsula.

Present work evaluates the non-decision as a selective technique of regulating political processes. Such an approach enables to include both reasons and consequences of non-decision into estimating the process of decision-making. The emphasis is made on that selective principles of political decision-making may have ambiguous influence on the stability of a political system, i.e. can reduce or enhance the risk of frustration of political process. On the case of Ukraine the study shows, how the non-decisions in the domestic and foreign affairs contributed to fixing frustration trends inside and outside the state and eventually led to an internal social crisis, a conflict with Russia and the loss of sovereignity over part of the territory.

Methods of research. The types of non-decisions presented and tested by Clun [7], Gregory [12], Judge [15], Sammon and McAvinue [22] are applied to the policy-making Ukraine, which served as a casestudy. The study is focused on the demonstration of those non-decision practices, which resulted into destructive consequences for Ukraine in 2013-2014. The key point in this analysis is that since getting independence in 1991, Ukraine's political system suffers from the systematic non-decision-making on strategic issues that led to essential delay of reforms, the lack of a clear position on the international arena, and internal disintegration of society. From other side, European political elites' non-decisions regarding Ukraineto-EU integration contributed to a vague geopolitical situation affecting a significant part of the continent.

Results. The non-decisions can be implemented in a number of ways: from using conventional procedures to manipulative practices focused on values and myths, and even the threat of using force. The most common technique of selective approach to policymaking is the rule of anticipated reactions [7; 12]. This approach is used when someone decides not to make claims to another in an attempt to avoid a direct confrontation, or because of concerns that such behavior could lead to sanctions against them. In the political sphere, governmental actors use this method through blocking opposition to enter the agenda the uncomfortable issues. In the international practice, the rule of anticipated reactions used to ensure the stability on the contentious issue, especially when the actors are unequal in their resource capabilities. Nonetheless, the consequences of this approach to decision-making can be long-term frozen conflicts. 
One of the most problematic issues facing Ukraine after the USSR collapse has been the demarcation of borders with neighboring countries. A rather uncertain situation occurred between Ukraine and Russia. Ukrainian government did not insist on the including the border demarcation between two countries into the agenda over a long time, and in fact this process has not been completed yet now. Along with many other reasons, it happened due to Ukraine's dependence on Russian energy supplies and the interconnections of markets in both countries. Russia repeatedly used the energy factor and trade embargo as tools for pressuring the Ukrainian government. Additionally, after the rejection of nuclear weapons and its destruction during the 1993-1996 Ukraine had become vulnerable to any external assault. The position of Russian government initially was ambiguous, because on the one hand, the Ukrainian-Russian agreements sealed the previous administrative borderlines and declared the sanctity, and on the other hand, the attempts of territorial claims were made.

The first wake-up call, as a consequence of such non-decision, took place in 2003, when Russia attempted to construct a dam in the Kerch Strait in the Azov Sea from the Taman Peninsula to the island of Tuzla. For the record, the island of Tuzla was formed by erosion due to heavy storm in 1925. This island has the area of 3 square kilometers, and in 1941 was joined to the Crimean Autonomous Republic, which in the status of the Crimean region in 1954 was included into the Ukrainian Soviet Socialist Republic [16]. The lack of official border clearly held in the waters of the Azov Sea and the Kerch Strait in particular, caused fuzzy demarcation of borders between Russia and Ukraine. Russia insisted that the official boundaries in the Azov Sea and the Kerch Strait were absent and refused to recognize Tuzla as an island, insisting that it was a spit. Russia pointed out that only the continental part of the Crimea became a Ukrainian territory and proposed joint use of the Azov-Kerch water area, agreeing with the establishment of the state border only on the bottom, but not on the water surface. Ukraine insisted that the Azov Sea and the Kerch Strait should be internal waters of Ukraine and the Russian Federation, separated by a state border. By such a separation, Tuzla belongs to Ukraine. The conflict was averted by diplomatic means. In 2003, the "Treaty between Ukraine and the Russian Federation on the Ukrainian-Russian state border" [24] delimited land and sea Ukraine-Russian border. Still obviously that for Russia the Azov Sea played the role of springboard move to the Crimean Peninsula, where its Black Sea Fleet was based.

The status of the Black Sea fleet, which was commonly inherited by Ukraine and Russia from the USSR, also was not long imposed on the agenda in Ukraine. In 1997, an Agreement was signed on the conditions of the Russian Black Sea fleet in the Crimea peninsula
[26]. However, that document did not include a clearly fixed status of the Black Sea Fleet in Ukraine. Note that the Russian Black Sea Fleet in Ukraine was among numerous significant legal barriers to applying for membership in the North Atlantic Alliance. This situation was favorable for Russia that did not want to release Ukraine from its geopolitical pool. However, it played a fatal role for Ukraine as in early March 2014 the battleships of the Black Sea Fleet blocked several Ukrainian ships, and Russian troops quickly seized the Ukrainian military base in Crimea.

It is symptomatic that in a moment of crisis, facing the loss of sovereignty over a part of the country's territory, the Ukrainian political elite once again took advantage of the rule of anticipated reactions, since after the detachment of the Crimean peninsula Kiev government has not followed a concerted operational solution to armed resistance to Russian aggression. The use of weapons by Ukrainian side could be considered by Russia as a holdfast for a full-scale attack on Ukraine. Consequently, Ukraine lost part of the territory and maritime borders. The unresolved problem of separation of borders with Russia and the status of the Black Sea Fleet in Ukraine certainly were not the only factors in that crisis.

Ignoring cultural variables is another systemic characteristic of policy-making in Ukraine. The cultural differences between Eastern and Western regions of Ukraine are historically determined and thus require carefully balanced cultural and, above all, language policy. The language situation in Ukraine is complicated. The official language in the country is Ukrainian, but Russian language is very widespread and quantitatively has very close frequency of usage to that of Ukrainian. Historically, Russian became the language of the majority urban population in Eastern areas of Ukraine. In such a bilingual country, for a long time the Ukrainian elite sought to implement the language policy by addressing historical deformation of the Ukrainian language in all spheres of society. As expected, this language policy met oppression in the Eastern regions of Ukraine, where the proportion of the Russian-speaking population is dominant. The failure to approve the law on language policy during the years of independence made it possible for elites to use the language issue as a manipulative tool to mobilize public prejudices of Eastern and Western regions to obtain electoral support. The issue of the Russian language became a speculative instrument, inciting voters to certain electoral exposures. The ingrained prejudice against ukrainization contributed to the loyalty of the population of Luhansk and Donetsk regions and Crimea to their occupation by Russian troops.

Besides the lack of consolidated decisions on language issue, no comprehensive solutions on decommunization of society have been implemented. In Eastern European states the decommunization was 
an important factor in the consolidation of society around the idea of modernization and entry into NATO and the European Union. By contrast, in Ukraine the Communist Party was active until 2014. The electorate of the Communist Party, mostly Russian-speaking, older age population, was essentially represented in Eastern regions and Crimea. The Communists' rhetoric was built on criticism of Ukraine's movement towards European integration, speculation on fears of outbreaks of nationalism, as well as the operation of the older generation's nostalgic attitude towards the Soviet past and the desirability of the restoration of the USSR. Such manipulative means not only cultivated a negative public opinion about the European integration prospects of Ukraine, but also had a disintegration impact on the country, dividing it into Western, pro-European and Eastern, pro-Russian regions. Disintegrated society is a comfortable electoral springboard for politicians to build electoral programs on antagonistic populist slogans. Yet, this situation lays risks to the stability of the political regime and the state as a whole entity.

That became possible mainly because during the period of independence Ukrainian authorities did not undertake adequate counter-measures against Kremlin's propaganda. Lack of strategic decisions on the part of the government to protect its own information area finally became a factor of social destabilization inside, and distortion of ideas about Ukraine outside.

Definitial games was one of the key tools of political manipulation in escalation of the conflict in Eastern Ukraine and Crimea annexation by Russia. This factor still doesn't allow to reach a consensus on resolving the crisis. From the very beginning the estimates of the conflict situation in Ukraine were significantly different between the Ukrainian government, Russian and Western authorities. From Ukrainian point of view the situation in late 2013 and early 2014 and the «Euromaidan» movement is regarded as the overthrow of the corrupt regime of President Yanukovych in terms of "Revolution of Dignity". Russia's actions towards Ukraine are recognized as military aggression. Western political and scientific community often assesses the situation in Ukraine in the terms of "the crises in and around Ukraine" [25], "aggression against Ukraine" [11], "conflict in Ukraine" [13], [19]. By contrast, Russian authorities have interpreted the political crisis in Ukraine as illegitimate overthrow of the government, and the introduction of Russian troops on the territory of Ukraine took place under the slogan of protecting Russian-speaking population from the surge of nationalism. The presence of Russian regular troops in Donetsk and Lugansk have been denied by substituting them as "humanitarian mission" of Russian "volunteers" [20]. By manipulating definitions, the Russian authorities during the negotiations in Minsk shied away from decision-making on the withdrawal of troops from the territory of Ukraine. The difference in the defining the situation in Ukraine, purposeful avoidance of recognizing the role of Russia as the aggressor, leaves to the latter space for maneuvers and subsequent speculation, and defers the opportunity to end the conflict.

Nevertheless, "the definitial games" played a destructive role much earlier then current conflict occurred. Political attitude of the European Union towards the neighboring countries has been widely criticized. Since the proclamation of the Communication "Wider Europe Neighbourhood: A New Framework for Relations with our Eastern and Southern Neighbours" [8], scientists point to manipulation in determining the status of countries that were close to the EU borders (see [1]). Realizing the complexity of enlargement, European elites initially sought a suitable category for countries that find themselves close to its borders and did not get into the EU. The European Union wanted to define a new range of policies as for its neighbors, based on freedom, democracy, respect to human rights and rule of law. However, it should be considered separately from the issue of possible EU membership. This document was sharply criticized as it offered a common approach to countries too different in terms of most criteria. As Wallace noticed "The EU's post-2004 eastern neighbors thus constitute what officials in Brussels now describe as a "grey zone": neither accepted as definite candidates, nor clearly denied the long-term prospect of membership" [27]. In 2004, all the countries on the southern and eastern borders of the EU were granted the status of "neighbors" [9].

In 2009, eastern "neighbors" were renamed as "partner countries" [14] within European Eastern Partnership. Despite the European aspirations of Ukraine, the EU did not provide opportunities to start negotiations on the Association, offering regular new definitions of the status of Ukraine as part of the EU foreign policy. Certainly, a country with a weak economy, affected by corruption and political instability was undesirable in the European Union, which thus had a significant economic burden for pulling new economies of its members to the European level. Still the lack of clear European prospects for the Ukrainian society badly affects the consolidation of the elites and the public mood about their civilizational values and priorities.

The method of disqualification comprises the prevention of the development of decision by appeal to non-qualification of its initiators on a specific set of problems. In terms of international relations, the disqualification can be regarded as a method of prevention solution to meet actor appealing to their non-compliance with certain criteria. For a quiet a long period Ukraine was refused to be included into the list of countries that are to enter the EU. For this the reforms were needed that would ensure the achievement 
of European standards. Neither the EU nor NATO provided clear signals to any prospects of Ukraine's membership, all the while appealing to non-compliance of Ukraine with European standards of democracy, economics and law. Notice, despite the obvious pro-Russian orientation of the Yanukovych's political circles it was on his presidency that EU leaders started to treat loyally deepening relations with Ukraine. After all, in 2012 the initialing of the Association Agreement with the EU took place.

As the non-decision tool towards Ukraine European politicians have been using the way of focus on monitoring, review and study. This method is used by international organizations as member-states not wanting to direct intervention in resolving the crisis, defer the decision on the operational performance or sanction mechanisms by implementing long-term monitoring missions [15]. By long-term monitoring Ukrainian reforms European politicians appeal to the inability of Ukraine to acquire a format of close relations with the $\mathrm{EU}$, thereby postponing the need for political and economic instruments for the gradual inclusion of Ukraine into the European integration area. At the other hand, Ukrainian government actively used a method of stressing positive achievements regardless of their rate of importance or necessity to European integration. This technique has become one of the most common mechanisms for Ukrainian politicians' reporting to the constituents and international institutions. Holding on focusing some events of a whole-Europe interest, e.g. the football championship Euro2012 , or claiming the absence of ethnic conflicts on the territory of Ukraine were presented by ruling authority, as an important achievement on the background of the lack of real social reforms.

Rejection through negative association has become the main form of non-decision on the conclusion of Ukraine Association Agreement (AA) [2] with the EU at the EU summit in Vilnius in 2013. Why did Ukrainian government and President Yanukovych refuse to sign the agreement, which has already passed the initialing and had to push EU-Ukraine relations to the new stage? Failure through a negative association is more the result of a number of other manipulative methods of non-decisions, which had to be prepared both inside and outside for refusing to sign the AA. In particular, using practices over-simplification and over-complexity in providing information on European integration on the eve of the signing the Agreement the public opinion on this issue was quite polarized.

Over-simplification involves the exclusion of categories and cause-effect relationships between them. The structure of the presentation of information enables to avoid recognition of relationships between its key elements, even if they have functional interdependence. This approach is often used in the media and is determined by the necessity of comfort presentation of the text. Over-simplification became one of the key trends in the post-democratic process, particularly in Western political systems, when politics and political parties use the techniques of advertising technology to formulate their programs as products available for the perception of broad sectors of the electorate. Ukrainian authorities used this method actively during a public discussion on the Association Agreement with the European Union in 2013, which was being described as an antagonistic opposition to the cooperation with Russia. Pro-European political forces called for signing by appeal to the possibility of acquiring a visa-free entrance to the EU that supposedly could allow improving the welfare of citizens. Those who were prone to developing relations with Russia appealed to the unavailability of Ukraine to European integration because of the danger of destruction of industries that would not survive the competition at the European market, thus threatening imminent unemployment. In fact, the public discourse on European integration was limited to mutually exclusive possibilities of relations with Russia, as Western vector acts versus Russian direction. Note, that simplifying the problems of European integration to the format of foreign policy dilemmas has been repeatedly useful for Ukrainian politicians during election processes. Appealing to common culture and historical past, proponents of Russia were passing concepts of brotherly Slavic peoples, e.i. Ukrainians and Russians. The residents of the eastern regions bordering Russia were particularly vulnerable to such manipulative allegations. Residents of the Western regions of Ukraine, who are more likely to have been in the EU mainly for low earnings, perceived pro-integration slogans as an opportunity to transfer to Ukraine the experience of Central and Eastern Europe where the standards of living of ordinary people are much higher. Using antagonistic attitudes on external priorities, politicians structured their electoral fields. The main factors that allowed such a manipulation were a weak awareness of the real components of the integration process and the lack of far-sighted strategy to adapt the format of relations with Russia in case of signing the EU Association Agreement.

As a result, on the eve of signing AA the Ukrainian society was extremely polarized on this issue. In particular, a public opinion poll on this issue, conducted in September 2013, showed that although most citizens (61.2\%) knew about the Association Agreement with the European Union, this indicator varied significantly by region. More than a third of residents in the North (44.1\%), the East (31.9\%), the South (30.4\%) and the Autonomous Republic of Crimea (32.2\%) were not informed on this issue. $48.8 \%$ of the respondents indicated that they lacked information on the prospects and risks of signing the Association Agreement with the European Union 
[6, p. 180]. The over-simplified presenting information on the European integration allowed to formulate an informed understanding of the citizens' objective content of relations between Ukraine and the European Union, but also contributed to the local social conflict inside the country.

Another exclusive method is over-complexification, which is widely practiced by experts in order to restrict access to a particular area of expertise. This selective mechanism works due to the complexity and increasing specialization of certain matters being on the agenda of political control. Obviously, the average citizen cannot be fully competent with political, economic, cultural and other aspects of society. However, a common trend in Ukrainian politics - the daily appeals to experts' opinion in narrow sphere of interest, but with lack of experience in public administration - led to a significant deformation of the reforms, as the issues that go beyond their specialization fall out of the field of professional vision. Given the fact that ordinary individuals do not have a clear picture of such complex messages, the appeal to the authoritative source operating with large amounts of data is an effective method of selective formation of general position in public in a desirable way.

Exertion of pressure became a core element in the relations between Russia and Ukraine. Russia's position regarding Ukraine always had the character of the metropolis. Without Ukraine, the ideas of Russian world and Russia's imperial ambitions have no much sense. Because of the increasing political gravity of Ukraine towards Europe, Russia resorted to every exertion of pressure by trade wars and energy supply regulations. Through prohibition of a number of goods and systematic violations of customs operations on the Ukraine-Russian border, Russia has sought to demonstrate potential aftermath for Ukraine's signing the Association Agreement with the EU. Eastern regions of Ukraine appeared to be especially sensitive for such measures, as most of regional export went to Russian Federation.

The issue of price on gas is crucial for Ukrainian and thus is used by Russia as probably the most effective tool of pressure on Ukrainian government. It was applied for forcing not to sign the EU Association Agreement at Vilnius summit in November 2013. The worst scenario of using exertion of pressure became a non-decision of Ukrainian authorities to go for dialogue with the citizens of their country. The use of force during demonstrations of «Euromaidan», intimidation and beatings of students in Kiev provoked a massive protest movement in Ukraine, which subsequently grew into armed confrontation and led to the ouster of Yanukovych. Yet, if for Yanukovych his non-decision cost him presidency, the large number of citizens paid their lives for this, first during the confrontation right in Kiev, and later during the conflict in the Donetsk and Luhansk regions.
Proposal of solutions based of unacceptable criteria as non-decision mechanism provides for the nomination of initiatives in order to gain widespread approval (in case of unwillingness to implement it in practice), offering a form of assistance to be rejected in advance as unacceptable. The method is widely used in complex international negotiations. In particular, during the Minsk negotiations to resolve the crisis in the Luhansk and Donetsk regions Russian side has repeatedly put forward proposals under the banner of assistance in resolving the conflict, which a priori cannot be taken by Ukraine, not to mention a non-compliance of these suggestions with the principles of international cooperation. Requirements to provide elections on the occupied territories are in conflict with very high level of danger of everyday attacks. In addition, it will require recognition of the status of autonomous self-governing administrative units for the radical separatist groups, which get support from Russia. Both demands are unacceptable for the Ukrainian side.

Delay as a technique of non-decision-making turned into a modus vivendi for implementing reforms in Ukraine. In fact, all the above-mentioned decisions and range of urgently needed reforms fall into this category. Postponing of the introduction of European standards of governance, transparency and citizens' control is typical for Ukrainian power-holders. Delay in judicial and law enforcement, medical and educational fields, the delay of Conclusions

This work is an attempt to revisit the question of political turbulence in modern international relations, in particular related to the conflict situation in Ukraine, from the methodological position of the non-decision and selective risk regulation concepts. In the theoretical aspect, we tried to challenge the key statement that a selective approach to decision-making is to prevent tension on sensitive public issues and to reduce shock-event factors. We argue that non-decision-making based on manipulative and heresthetic techniques can have a destructive impact on the political system and entire society.

Conclusions. Based on the most typical non-decision practices, this research demonstrated how selectivity in developing agenda and the active use of manipulative techniques to prevent decision-making in both domestics and foreign affairs led to a political and social crisis in Ukraine and imbalance of security in Europe. Among the key non-decisions, which caused internal instability of the political system and the weak position of the state as for external actors, including Russia, the lack of clearly defined foreign policy strategy was the most destructive. During the years of independence, the Ukrainian authorities tried to «sit on two chairs», declaring intentions of integration both to the European and Eurasian economic and political entities. Even proclaiming its commitment to the Association with the EU since the mid-2000s, the Ukrainian 
authorities have not demonstrated the consistency of proper integration policy providing complex legal and institutional measures. Such tactics of Ukrainian power-holders resulted from the expected reactions to rule of anticipated reactions, mostly from Russia. The latter constantly and actively used various tools of pressure on Ukraine (energy and trade wars), trying to prevent the drift of Ukraine towards European institutions. Unwilling to escalate tensions with Russia but flirting with the EU, the Ukrainian government really succeeded for a certain period to ensure stability in the region. But lightning Russia's actions in March 2014 regarding the occupation of the Crimea, then taking part in starting the armed conflict in the Eastern regions of Ukraine have shown evidence of the fragility of stability.

If external aggressive intentions of the Kremlin for the last decade were obvious, the European Union has been using a practice of "definitial games" in modeling relations with countries on the Eastern border, postponing decisions about their real status in the political space of Europe. The "delay" in defining European integration prospects of Ukraine and rather long "disqualification" from those selected for membership were the main techniques of non-decision by the EU, which, in turn, became an adverse factor for rather vague and inconsistent policy of Ukraine. Yet the most dangerous in its consequences is manipulative practices of non-decision in internal processes. "Ignoring cultural variables" by Ukrainian authorities in developing solutions that would consolidate Ukrainian society, while their manipulation to obtain electoral benefits, led to polarization of public perceptions on foreign and internal perspectives. In such a society as Ukrainian, where significant regional cultural and mental differences exist, a long delay or lack of consolidating decisions eventually may turn into disintegration tendencies. A sufficient number of factors contribute to that process to make the system collapse inevitable.

Analysis of non-decisions that caused the conflict situation in Ukraine and threatened the stability of security in Europe, can be deployed at the macro-level in the context of sharpening confrontation between Russia and the West, delegitimizing global order, inefficiencies of institutional mechanisms for regulating international relations (including non-decision on reforming the UN and NATO). Thereby, this study aimed to show how selective approach to decision-making, bringing short-term dividends, in long term and systematic use carries serious risks for all involved parties. Finally, one should note that the political elites are always interested in preserving the status quo, seeking to expand the scale of influence and weaken those who do not support them in order to suppress a decision that could change their position. However, mobilization of bias can be prevented or at least the degree of manipulative influence can be reduced through the increased public involvement in politi- cal decision-making and, more importantly, improve their awareness of issues of political governance.

\section{BIBLIOGRAPHY:}

1. Apap J., Tchorbadijyska A. What about neighbors? The impact of Schengen along the EU's external borders. CEPS Working Document. Center for European Policy Studies (CEPS). Brussels, 2004. No. 210. URL : http://unpan1.un.org/intradoc/groups/public/documents/UNTC/UNPAN018877.pdf.

2. Association Agreement between the European Union and its Member States, of the one part, and Ukraine, of the other part. Official Journal of the European Union. 2014. L 161/3. URL : https://eeas.europa.eu/sites/eeas/ files/association_agreement_ukraine_2014_en.pdf.

3. Bachrach P., Baratz $\bar{M}$. S. Two faces of power. American political science review. 1962. Vol. 56, No. 4. P. 947-952. DOI: 10.2307/1952796.

4. Bachrach P., Baratz M.S. Decisions and nondecisions: An analytical framework. American political science review. 1963. Vol. 57, No. 3. P. 632-642. DOI: $10.2307 / 1952568$.

5. Bachrach P., Baratz M.S. Power and poverty. Theory and practice. New York: Oxford University Press, 1970. $220 \mathrm{p}$.

6. Балакірєва О., Дмитрук, А. Інтеграційні орієнтації населення: Осінь 2013 р. Моніторинг громадської думки. Український соціум. 2013. №4(47). C. 175-187. URL : https://ukr-socium.org.ua/wp-content/uploads/2013/10/175-187_no-4_vol-47_2013_ UKR.pdf.

7. Clun A. The rule of anticipated reactions. Political science and politics. 1974. Vol. 7, No.1. P. 12. DOI: 10.1017/S1049096500010714.

8. Wider Europe Neighbourhood: A new framework for relations with our Eastern and Southern neighbours: Communication from the Commission to the Council and the European Parliament. Brussels. 11.03.2003. URL : http://eeas.europa.eu/archives/docs/ enp/pdf/pdf/com03_104_en.pdf.

9. European Neighbourhood Policy. Strategy paper: Communication from the Commission. Brussels. 12.05.2004. URL : http://www.europarl.europa. eu/meetdocs/2004_2009/documents/com/com_ com(2004)0373_/com_com(2004)0373_en.pdf.

10. Frey F. Comment: On issues and nonissues in the study of power. American political science review. 1971. Vol. 65, No. 4. P. 1081-1101. DOI: 10.2307/1953499.

11. Grant T. Aggression against Ukraine: Territory, responsibility, and international law. New York : Palgrave Macmillan, 2015. 283 p.

12. Gregory R. Local elections and the «rule of anticipated reactions». Political studies. 1969. Vol. 17, No. 1. P. 31-47. DOI:10.1111/j.1467-9248.1969.tb00623.x

13. Haukkala $\mathrm{H}$. From cooperative to contested Europe? The Conflict in Ukraine as a culmination of a long-term crisis in EU-Russia Relations. Journal of contemporary European Studies. 2015. Vol. 23, No. 1. P. 25-40. DOI:1080/14782804.2014.1001822.

14. Joint Declaration of the Prague Eastern Partnership Summit Prague. Council of the European Union. Brussels, 07.05.2009. No. 8435/09 (Press 78), URL : http://www.consilium.europa.eu/uedocs/cms_ data/docs/pressdata/en/er/107589.pdf. 
15. Judge $A$. The art of non-decision-making and the manipulation of categories. 1997. URL : http://www.laetusinpraesens.org/docs/nondec.php.

16. Касяненко Ю. Я. Закон СРСР «Про передачу Кримської області зі складу РРФСР у склад Української РСР» 1954 / Касяненко Ю.Я. [Електронний ресурс] / Енциклопедія історії України: Т. 3: Е-Й / Редкол.:В.А. Смолій (голова)таін. НАНУкраїни. Інститут історії України. Київ : Наукова думка, 2005. 672 с. URL:http://www.history.org.ua/?termin=Zakon_SRSR_Pro peredachu_Krymskoy_obl_1954.

17. Lukes S. Power. A radical view. London : Palgrave Macmillan; 2nd edition. 2005. 192 p.

18. McGrew A.G., Wilson M. J. Decision making: Approaches and analysis: a reader. Manchester: Manchester University Press in association with the Open University, 1982. 408 p.

19. Menon R., Rumer E. Conflict in Ukraine: The unwinding of the Post-Cold War order. USA. Cambridge. MA: MIT Press, 2015. 240 p.

20. Oliphant R., Sabur R. Vladimir Putin admits: Russian troops «were in Ukraine». After two years of resolute denials, the Russian president admits that he sent soldiers into eastern Ukraine after all. The Telegraph. 17.12.2015. URL : https://www.telegraph.co.uk/news/ worldnews/vladimir-putin/12054164/Vladimir-Putins-annual-press-conference-2015-live.html.

21. Riker W. The art of political manipulation. New Haven, Conn.: Yale University Press, 1986. 152 p.

22. Sammon D., McAvinue, D. Investigating non-decision making during an ERP software selection process, In: Proceedings of the 2004 IFIP International Conference on Decision Support Systems (DSS2004), Italy. Tuscany. Prato. 1-3 July 2004. Prato, 2004. P. 703-713, URL : http://citeseerx.ist.psu.edu/viewdoc/download?doi=10.1.1.2.3467\&rep=rep1\&type=pdf.

23. Schattschneider $E$. The semisovereign people: A realist's view of democracy in America. New York : Holt, Rinehart and Winston. 1960. 176 p.

24. Договір між Україною і Російською Федерацією про українсько-російський державний кордон (укр./рос.) Підписано 28.01.2003. Ратифріковано Законом України №1681-IV (1681-15) від 20.02.2004. URL : http://zakon2.rada.gov.ua/laws/ show/643_157 (дата звернення 14.10.2020).

25. Troika statement on the crises in and around Ukraine. Permanent Mission of the Federal Republic of Germany to the OSCE Vienna, 08.12.2017. MC.DEL/31/17. URL : https://www.osce.org/files/f/ documents/8/8/361786.pdf.

26. Угода між Україною і Російською Федерацією про статус та умови перебування Чорноморського фрлоту Російської Федерації на території України (укр/рос). Підписано 28.05.1997. Ратисріковано Законом України № 547-XIV (547-14) від 24.03.1999. Відновлено https://zakon.rada.gov.ua/laws/show/643 076\#Text (дата звернення 14.10.2020).

27. Wallace W. Looking after the Neighborhood: Responsibilities for the EU-25. Policy Paper. 2003. No. 4. URL : https://institutdelors.eu/wp-content/ uploads/2018/01/policypaper4.pdf.

28. Zolo D. Democracy and complexity. A realist approach. Cambridge: Polity Press in association with Blackwell Publishers, 1992. 220 p.

\section{REFERENCES}

1. Apap, J. and Tchorbadijyska A. (2004). What about Neighbors? The Impact of Schengen along the EU's external borders. Center for European Policy Studies (CEPS): CEPS Working Document. No. 210. URL: http://unpan1.un.org/intradoc/groups/public/documents/ UNTC/UNPAN018877.pdf

2. Association Agreement between the European Union and its Member States, of the one part, and Ukraine, of the other part. (2014). Official Journal of the European Union. L 161/3. URL: https://eeas.europa.eu/sites/ eeas/files/association_agreement_ukraine_2014_en.pdf

3. Bachrach, P. and Baratz, M. S. (196̄2). Two faces of power, American Political Science Review, vol. 56, no. 4, pp. 947-952. DOI: 10.2307/1952796.

4. Bachrach, P. and Baratz, M.S. (1963). Decisions and nondecisions: An analytical framework, American Political Science Review, vol. 57, no. 3, pp. 632-642. DOI: $10.2307 / 1952568$

5. Bachrach, P. and Baratz, M.S. (1970). Power and poverty. Theory and practice. New York: Oxford University Press. $220 \mathrm{p}$.

6. Balakirieva, O. i Dmytruk, A. (2013). Intehratsiini oriientatsii naselennia: Osin 2013 r. Monitorynh Hromadskoi Dumky [Integration orientations of the population: Autumn 2013. Monitoring of Public Opinion]. Ukrainskyi sotsium, No.4 (47), pp. 175-187. URL: https://ukr-socium.org.ua/wp-content/uploads/2013/ 10/175-187_no-4_vol-47_2013_UKR.pdf[inUkrainian].

7. Clun, $\bar{A} .(19 \overline{74})$. The Rule of anticipated reactions. Political Science and Politics, vol. 7, no.1, p. 12. DOI: 10.1017/S1049096500010714

8. Wider Europe Neighbourhood: A New Framework for Relations with our Eastern and Southern Neighbours. (2003, March 11). Communication from the Commission to the Council and the European Parliament. Brussels. URL: http://eeas.europa.eu/archives/docs/enp/pdf/pdf/ com03_104_en.pdf

9. European Neighbourhood Policy. (2004, May 12). Communication from the Commission.. Strategy Paper. Brussels.URL:http://www.europarl.europa.eu/meetdocs/ 2004_2009/documents/com/com_com(2004)0373_I com_com(2004)0373_en.pdf

10. Frey, F. (197̄1). Comment: On issues and nonissues in the study of power. American Political Science Review, vol. 65, no. 4, pp. 1081-1101. DOI: $10.2307 / 1953499$

11. Grant, T. (2015). Aggression against Ukraine: Territory, responsibility, and international law. New York: Palgrave Macmillan. 283 p.

12. Gregory, R. (1969, March) Local elections and the "rule of anticipated reactions", Political Studies, vol. 17, no. 1, pp. 31-47. DOI:10.1111/j.1467-9248.1969. tb00623.x

13. Haukkala, H. (2015). From cooperative to contested Europe? The Conflict in Ukraine as a culmination of a long-term crisis in EU-Russia Relations, Journal of contemporary European Studies, vol. 23, no. 1, pp. 25-40. DOI:1080/14782804.2014.1001822

14. Joint Declaration of the Prague Eastern Partnership Summit Prague. (2009, May 7). Council of the European Union. Brussels, 8435/09 (Press 78), URL: http://www.consilium.europa.eu/uedocs/cms_data/ docs/pressdata/en/er/107589.pdf 
15. Judge, A. (1997). The Art of Non-Decision-Making and the Manipulation of Categories. URL: http://www. laetusinpraesens.org/docs/nondec.php

16. Kasianenko, Yu. Ya. (2005). Zakon SRSR «Pro peredachu Krymskoi oblasti zi skladu RRFSR u sklad Ukrainskoi RSR» 1954. [The Law of the USSR "On The Transfer of the Crimean Region from the Composition of the RSFSR in the Composition of the Ukarinian SSR 1954"] Kasianenko Yu.la. [Elektronnyi resurs] / Entsyklopediia istorii Ukrainy: T. 3: E-Y / Redkol.: V. A. Smolii (holova) ta in. NAN Ukrainy. Instytut istorii Ukrainy. Kyiv: Naukova dumka, 672 s. URL: http://www.history.org.ua/?termin=Zakon_SRSR_Pro_ peredachu_Krymskoy_obl_1954 [in Ukrainian].

17. Lukes, S. (2005). Power. A radical view. London: Palgrave Macmillan; 2nd edition. 192 p.

18. McGrew, A.G. and Wilson, M. J. (1982). Decision making: Approaches and analysis: a reader. Manchester: Manchester University Press in association with the Open University, 408 p.

19. Menon, R. and Rumer, E. (2015). Conflict in Ukraine: The unwinding of the Post-Cold War order. USA. Cambridge. MA: MIT Press. 240 p.

20. Oliphant, R. and Sabur, R. (2015, 17 December). Vladimir Putin admits: Russian troops "were in Ukraine". After two years of resolute denials, the Russian president admits that he sent soldiers into eastern Ukraine after all. The Telegraph. https://www.telegraph.co.uk/news/ worldnews/vladimir-putin/12054164/Vladimir-Putinsannual-press-conference-2015-live.html

21. Riker, W. (1986). The art of political manipulation. New Haven, Conn.: Yale University Press. 152 p.

22. Sammon, D. and McAvinue, D. (2004, July 1-3) Investigating non-decision making during an ERP Software selection process, In: Proceedings of the
2004 IFIP International Conference on Decision Support Systems (DSS2004), Prato, Tuscany, Italy, pp. 703-713, URL: http://citeseerx.ist.psu.edu/viewdoc/download? doi=10.1.1.2.3467\&rep=rep1\&type=pdf

23. Schattschneider, E. (1960). The semisovereign people: A realist's view of democracy in America. New York: Holt, Rinehart and Winston. 176 p.

24. Dohovir mizh Ukrainoiu i Rosiiskoiu Federatsiieiu pro ukrainsko-rosiiskyi derzhavnyi kordon (2004). Ratyfikovano Zakonom №1681-IV (1681-15) [Treaty between Ukraine and the Russian Federation on the Ukrainian-Russian State Border]. Pidpysano 28.01.2003. Katyfikovano Zakonom No.1681-IV (1681-15), (2004, April 20) http://zakon2. rada.gov.ua/laws/show/643_157 [in Ukrainian].

25. Troika Statement on the crises in and around Ukraine (2017, 8 December). MC.DEL/31/17. Permanent Mission of the Federal Republic of Germany to the OSCE Vienna. URL: https://www.osce.org/files/f/ documents/8/8/361786.pdf

26. Uhoda mizh Ukrainoiu i Rosiiskoiu Federatsiieiu pro status ta umovy perebuvannia Chornomorskoho flotu Rosiiskoi Federatsii na terytorii Ukrainy. [Agreement between Ukraine and the Russian Federation on the Status and Conditions of Black Sea Fleet Russian Federation in Ukraine] Pidpysano 28.05.1997. Ratyfikovano Zakonom № 547-XIV (547-14) (1999, March 24). URL: http://zakon3.rada.gov.ua/laws/ show/643_076 [in Ukrainian].

27. Wallace, W. (2003). Looking after the Neighborhood: Responsibilities for the EU-25. Policy Paper. No. 4. URL: https://institutdelors.eu/wp-content/ uploads/2018/01/policypaper4.pdf

28. Zolo, D. (1992). Democracy and complexity. A realist approach. Cambridge: Polity Press in association with Blackwell Publishers. 220 p.

\section{Ризики неухвалення політичних рішень (на прикладі України)}

Вінникова Наталія Анатоліївна

кандидат політичних наук, доцент, доцент кафедри політології Харківського національного університету імені В. Н. Каразіна майдан Свободи, 4, Харків, Україна у статті представлена спроба розширити ракурс досліджень щодо розвитку міжнародних подій в останні роки, зокрема збройного конорлікту на території України, шляхом залучення як теоретико-методологічної основи концепцій не-рішень та селективного регулювання ризиків.

Метою чієї роботи є розкриття найбільш значущих не-рішень у сфрері внутрішньоі та зовнішньої політики України з моменту здобуття незалежності, які призвели до суттєвої затримки реформ, відсутності чіткої позиції на міжнародній арені та внутрішньої дезінтеграції суспільства, зрештою зумовили посилення фррустраційних тенденцій, призвели до кризи всередині держави, консрлікту з Росією і втрати суверенітету над частиною території. Оскільки внутрішня криза в Україні спричинила напруженість між європейськими країнами та Росією, до аналізу також включена зовнішня політика ЄС щодо своїх східних сусідів та України зокрема.

У дослідженні не-рішення розглядаються як селективний прийом регулювання політичних процесів. Такий підхід дозволяє включати в оцінювання політичних рішень як причини, так і наслідки їх неухвалення. У теоретичному аспекті полеміці піддається ключове твердження концепції селективного регулювання ризиків, згідно з яким вибірковий підхід до ухвалення рішень покликаний забезпечити стабільність політичної системи. Стверджується, що неухвалення рішень за допомогою маніпулятивних та герестетичних прийомів у процесі фрормування політики може мати руйнівний вплив і призвести до руйнівних наслідків для політичної системи. Аналіз теоретичних напрацювань, інституційних механізмів та практик запобігання ухваленню політичних рішень дозволив дійти таких висновків: 1) всебічне вивчення наслідків будь-якого політичного рішення повинно містити аналіз потенційних сценаріїв його неухвалення; 2) функціональний аспект політичної системи, а саме регулювання соціальних ризиків, забезпечує створення колективних правил і дозволяє суб'єктам діяти відповідно до стабільних суспільних очікувань, намагаючись виключити ризики і фррустрації із соціального життя, які можуть спричинити шокові події. Таким чином, у дослідженні продемонстровано, як селективний підхід до ухвалення політичних рішень, що приносить короткострокові дивіденди, у довгостроковому та систематичному використанні несе серйозні ризики для всіх залучених сторін.

Ключові слова: ухвалення рішень, не-рішення, мобілізація упередженостей, Україна. 